\title{
PROBLEMATIKA PEMBELAJARAN STATISTIK DI PERGURUAN TINGGI KEAGAMAAN ISLAM (PTKI)
}

\author{
Sri Irawati \\ Universitas Madura (UNIRA) Pamekasan \\ e-mail: dira.irawati@gmail.com)
}

\begin{abstract}
Abstrak:
Statistik merupakan pengetahuan yang berhubungan dengan caracara pengumpulan data, pengolahan atau penganalisisannya dan penarikan kesimpulan berdasarkan kumpulan data dan penganalisisan yang dilakukan. Upaya mengembangkan pendekatan dan strategi pembelajaran sudah banyak dilakukan dalam rangka memperbaiki kualitas pendidikan. Dengan modal pengalaman yang dimiliki selama aktif di dunia pendidikan dapat melahirkan inovasi dalam pembelajaran matematika/statistik, tidak sedikit pula hasil inovasi yang mereka lakukan memberikan hasil yang efektif. Permasalahan yang bersumber dari karakteristik matematika, Permasalahan yang bersumber dari media dan alat peraga, Permasalahan yang bersumber dari bahasa (simbol, huruf dan kata), serta Permasalahan yang bersumber dari Mahasiswa yang bersangkutan. Diantara solusi dari Dosen adalah Adanya peningkatan profesionalisme tenaga pendidik yang meliputi kompetensi personal, kompetensi pedagogik, kompetensi profesional dan kompetensi sosial.
\end{abstract}

Kata kunci : problematika, statistik, PTKI

\section{Abstract:}

Statistics is the science dealing with the ways of data collection, processing or penganalisisannya and drawing conclusions based on analyzing the data set and done. Efforts to develop approaches and learning strategies has been done in order to improve the quality of education. With the experience that capital active in the world for education can deliver innovation in the learning of mathematics/statistics, there are also the result of innovation they do provide very effective results. Problems derived from mathematical characteristics, problems originating from media and props, the problem comes from the language (symbols, letters and words), as well as the problems that come from the students. 
Among the solutions of the teacher is the presence of increased professionalism of educators that includes personal competence, pedagogical competence, professional competence and social competence.

Keywords : problems, statistics, Islamic college

\section{Pendahuluan}

Pepatah arab mengatakan, "Metodologi lebih penting dari pada materi" karena dalam anggapan semua orang, barang siapa yang sudah mampu menguasai metodologi, maka dapat dipastikan bahwa beliau mampu meyakinkan dan mampu mengkondisikan audien/ Mahasiswa.

Namun kemudian, menguasai metodologi bukanlah suatu hal yang final, karena bagaimanapun kita sebagai Dosen harus mampu memahami dan menguasai materi yang menjadi topik bahasan dalam rangka meningkatkan kompetensi profesional.

Selanjutnya, disamping penguasaan metodologi dan penguasaan materi yang baik, suatu hal yang tak kalah pentingnya juga adalah bagaimana seorang Dosen mampu menciptakan lingkungan belajar yang kondusif. Yang di dalamnya meliputi pengelolaan kelas, serta permasalahan lingkungan belajar. Dengan harapan, seluruh materi yang disampaikan mampu dicerna dan dipahami oleh peserta didik.

Hal ini kemudian tidak jarang terjadi dalam dunia pendidikan kita, ada diantara Dosen belum sepenuhnya memahami urgensi tentang materi ajar yang berbeda dengan basic keilmuan Mahasiswa, seperti statistik di PTKI. Atas dasar inilah, maka penulis berinisiatif mengupas serta berusaha untuk sedikit mencoba dan berikhtiar dalam rangka memperbaiki tradisi dan budaya negatif yang terjadi dikalangan Dosen dan Mahasiswa.

Apalagi objek dan kajian kita adalah Mahasiswa diluar jurusan matematika, dalam hal ini adalah Mahasiswa di Perguruan Tinggi Kegamaan Islam (PTKI) maka permasalahan semakin saja komplek, karena statistik merupakan cabang dari ilmu matematika yang bersifat hirarki, terstruktur dan sistematis. Artinya, Mahasiswa dituntut memiliki pengetahuan prasyarat dalam rangka memahami penjelasan pada bab berikutnya.

Dipahami bahwa Mahasiswa PTKI seperti halnya fakultas agama Islam, pada dasarnya mereka ingin menghindar dari pengetahuan yang bersifat angka-angka dan rumus. Tetapi, integrasi ilmu matematika dalam setiap rumpun ilmu pengetahuan 
senantiasa mewarnai dan menjadi mata kuliah wajib walaupun dengan istilah yang berbeda namun secara substansinya itu merupakan rumpun dan sub bahasan kajian ilmu matematika yaitu statistik.

\section{Pembahasan}

\section{Definisi Pembelajaran Dan Statistik}

Ada beberapa istilah kaitannya dengan pembelajaran, antara lain pendekatan pembelajaran, metode pembelajaran, dan model pembelajaran. Agar lebih mudah dipahami, maka secara eksplisit akan dijabarkan sebagai berikut:

Pendekatan pembelajaran adalah, cara yang ditempuh Dosen dalam pelaksanaan pembelajaran agar konsep yang disajikan dapat diadaptasikan oleh peserta didik. Dimana ada dua jenis dalam pembelajaran ilmu matematika yaitu pendekatan yang bersifat metodologis dan pendekatan yang bersifat materi. ${ }^{1}$

Metode pembelajaran adalah, cara menyajikan materi yang masih bersifat umum. Sedangkan model pembelajaran adalah, pola interaksi Mahasiswa dengan Dosen didalam kelas yang menyangkut strategi, pendekatan, metode dan teknik pembelajaran yang diterapkan dalam pelaksanaan kegiatan belajar-mengajar di kelas. Model pembelajaran matematika yang lazim diterapkan antara lain model pembelajaran klasikal, individual, diagnostik, remidial dan modul. ${ }^{2}$

Versi lain menyebutkan bahwa, ada tiga variabel pembelajaran antara lain, Pertama, kondisi pembelajaran yaitu faktor yang mempengaruhi efek metode dalam meningkatkan hasil pembelajaran. Kedua, metode pembelajaran yaitu cara-cara yang berbeda untuk mencapai hasil pembelajaran yang berbeda dibawah kondisi yang berbeda. Ketiga, hasil pembelajaran yaitu semua efek yang dapat dijadikan sebagai indikator tentang nilai dari penggunaan metode pembelajaran di bawah kondisi yang berbeda. $^{3}$

Statistik adalahpengetahuan yang berhubungan dengan caracara pengumpulan data, pengolahan atau penganalisisannya dan

1 Erman Suherman, at.al,Strategi Pembelajaran Matematika Kontemporer, (Bandung: UniversitasPendidikan Indonesia, 2003), 6.

2 Ibid, 7.

${ }^{3}$ Hamzah B. Uno, Perencanaan Pembelajaran, (Jakarta: PT Bumi Aksara, 2011), 16. 
penarikan kesimpulan berdasarkan kumpulan data dan penganalisisan yang dilakukan. ${ }^{4}$

Terdapat beberapa istilah dalam mata kuliah statistik antara lain: (1). Data adalah hasil observasi atau pengamatan yang telah dikumpulan; (2). Populasi, adalah kumpulan/himpunan semua objek yang menjadi perhatian peneliti; (3). Sensus, adalah koleksi data dari semua anggota dalam populasi; (4). Sampel, adalah himpunan bagian dari populasi; (5). Statistika Deskriptif, adalah cabang statistika dimana perhitungan maupun kesimpulankesimpulan dibuat sebatas data yang dikumpulkan; (6). Statistika Inferensial, adalah cabang statistika dimana kesimpulan berlaku luas; (7). Parameter adalah, sebuah bilangan rill yang menyatakan sebuah karakteristik dari populasi; (8). Statistik adalah, sebuah bilangan rill yang menyatakan sebuah karakteristik dari sampel; (9). Data Kuantitatif adalah, data yang menggambarkan hasil perhitungan atau hasil pengukuran; (10). Data Kualitatif adalah data yang dapat dipisahkan dalam beberapa kategori atau kelompok yangdibedakan oleh karakter bukan numerik; (11). Data Diskrit adalah, data yang diperoleh dengan menghitung atau membilang; (12). Data Kontinuadalah, data yang diperoleh dari hasil pengukuran. ${ }^{5}$

\section{Permasalahan Dalam Pembelajaran}

Secara etimologis, masalah diartikan sebagai ketidaksesuaian antara harapan dengan kenyataan, sementara belajar itu sendiri adalah proses perubahan pengetahuan atau perilaku sebagai hasil dari pengalaman seseorang.Maka masalah belajar dapat diartikan bahwa suatu kondisi tertentu yang dialami oleh murid dan menghambat kelancaran proses yang dilakukan individu untuk memperoleh suatu perubahan tingkah laku yang baru secara keseluruhan. ${ }^{6}$

Kondisi tertentu itu dapat berkenaan dengan keadaan dirinya yaitu berupa kelemahan-kelemahan dan dapat juga berkenaan dengan lingkungan yang tidak menguntungkan bagi dirinya.

Masalah-Masalah Internal Belajar, Dalam interaksi belajar mengajar Mahasiswa merupakan kunci utama keberhasilan belajar selama proses belajar yang dilakukan. Proses belajar merupakan aktivitas psikis berkenaan dengan bahan belajar. Untuk bertindak belajar Mahasiswa menghadapi masalah-masalah secara intern.

\footnotetext{
${ }^{4}$ Sudjana, Metoda Statistika, (Bandung: Tarsito, 2005), 3.

${ }^{5}$ Ibid, 5-7.

${ }^{6}$ Slameto, Belajar dan Faktor-Faktor Yang mempengaruhi, (Jakarta: Rineka Cipta, 1991),70.
} 
Jika Mahasiswa tidak dapat mengatasi masalahnya, maka ia tidak dapat belajar dengan baik. Terdapat beberapa faktor intern yang dialamai dan dihayati oleh Mahasiswa dan hal ini akan sangat berpengaruh terhadap proses belajar. Faktor-faktor tersebut akan diuraikan sebagai berikut:

Pertama, Sikap Terhadap Belajar, Sikap merupakan kemampuan memberikan penilaian tentang sesuatu, yang membawa dirinya sesuai dengan penilaian. Adanya penilaian terhadap sesuatu memberikan sikap menerima, menolak atau mengabaikannya begitu saja. Selama melakukan proses pembelajaran sikap Mahasiswaakan menentukan hasil dari pembelajaran tersebut. Sikap yang salah akan membawa Mahasiswa merasa tidak peduli dengan belajar lagi. Akibatnya tidak akan terjadi proses belajar yang kondusif. Tentunya hal ini akan sangat menghambat proses belajar. Sikap Mahasiswa terhadap belajar akan menentukan proses belajar itu sendiri.

KeduaMotivasi Belajar. Motivasi belajar merupakan kekuatan mental yang mendorong terjadinya proses belajar. Lemahnya motivasi atau tiadanya motivasi belajar akan melemahkan kegiatan belajar. Selanjutnya mutu belajar akan menjadi rendah. Oleh karena itu motivasi belajar pada diri Mahasiswa perlu diperkuat terus menerus.Motivasi yang diberikan dapat meliputi penjelasan tentang keutamaan ilmu dan keutamaan mencari ilmu. Bila Mahasiswa mengetahui betapa besarnya keutamaan sebuah ilmu dan betapa besarnya ganjaran bagi orang yang menuntut ilmu, maka Mahasiswaakan merasa haus untuk menuntut ilmu. ${ }^{7}$

Ketiga, Konsentrasi belajar. Konsentrasi belajar merupakan kemampuan memusatkan perhatian pada pelajaran. Pemusatan perhatian tersebut tertuju pada isi bahan belajar maupun proses memperolehnya. Untuk memperkuat perhatian Dosen perlu melakukan berbagai strategi belajar mengajar dan memperhatikan waktu belajar serta selingan istirahat. Yang perlu diperhatikan oleh Dosen ketika memulai proses belajar ialah sebaiknya seorang Dosen tidak langsung melakukan pembelajaran, namun seorang Dosen harus memusatkan perhatian Mahasiswanya sehingga siap untuk melakukan pembelajaran.

Keempat, Menyimpan Perolehan Hasil Belajar. Untuk mengatasi hal ini sebaiknya Dosen mengingatkan akan materi yang telah lama diberikan, serta memberikan pertanyaan yang berkaitan dengan materi tersebut. Sehingga mau atau tidak mau

7 S. Nasution, Berbagai Pendekatan Dalam Proses Belajar dan Mengajar, (Jakarta: Bumi Aksara, 2000), 20. 
Mahasiswaakan berusaha untuk mengingat kembali materi yang telah lama disampaikan serta membuka kembali buku yang berkaitan dengan materi tersebut. Sehingga Ingatan yang disimpan dalam jangka panjang akan semakin kuat. ${ }^{8}$

Kelima, Kemampuan berprestasi. Kemampuan berprestasi atau unjuk hasil belajar merupakan puncak suatu proses belajar. Pada tahap ini Mahasiswa membuktikan hasil belajar yang telah lama ia lakukan. Mahasiswa menunjukan bahwa ia telah mampu memecahkan tugas-tugas belajar atau menstransfer hasil belajar. Dari pengalaman sehari-hari di sekolah diketahui bahwa ada sebagian Mahasiswa tidak mampu berprestasi dengan baik.Kemampuan berprestasi tersebut terpengaruh pada prosesproses penerimaan, pengaktifan, pra-pengolahan, pengolahan, penyimpanan, serta pemanggilan untuk pembangkitan pesan dan pengalaman.

Keenam, Rasa percaya diri. Rasa percaya diri timbul dari keinginan mewujudkan diri bertindak dan berhasil.Dari segi perkembangan, rasa percaya diri dapat timbul berkat adanya pengakuan dari lingkungan. Dalam proses belajar diketahui bahwa unjuk prestasi merupakan tahap pembuktian perwujudan diriyang diakui oleh Dosen dan rekan sejawat Mahasiswa. Semakin sering Mahasiswa mampu menyelesaikan tugasnya dengan baik maka rasa percaya dirinya akan meningkat. Dan apabila sebaliknya yang terjadi maka Mahasiswaakan merasa lemah percaya dirinya.

Ketujuh, Intelegensi dan Keberhasilan Belajar. Intelegensi merupakan suatu kecakapan global atau rangkuman kecakapan untuk dapat bertindak secara terarah, berpikir secara baik dan bergaul dengan lingkungan secara efisien.Kecakapan tersebut menjadi actual bila Mahasiswa memecahkan masalah dalam belajar atau kehidupan sehari-hari. Dengan perolehan hasil belajar yang rendah, yang disebabkan oleh intelegensi yang rendah atau kurangnya kesungguhan belajar, berarti terbentuknya tenaga kerja yang bermutu rendah. Hal ini akanmerugikan calon tenaga kerja itu sendiri. Oleh karena itu pada tempatnya mereka didorong untuk melakukan belajar dibidang keterampilan.

Kedelapan, Kebiasaan-kebiasaan belajar Mahasiswa. Kebiasaan-kebiasaan belajar Mahasiswa akan mempengaruhi kemampunanya dalam berlatih dan menguasai materi yang telah disampaikan oleh Dosen. Kebiasaan buruk tersebut dapat berupa belajar pada akhir semester, belajar tidak teratur, menyia-nyiakan kesempatan belajar, bersekolah hanya untuk bergengsi, datang

8 Muhibbin Syah, Psikologi Belajar, (Jakarta: PT Grafindo Persada, 2006), 10. 
terlambat bergaya pemimpin, bergaya jantan seperti merokok. Kebiasaan-kebiasaan buruk tersebut dapat ditemukan di sekolahsekolah pelosok, kota besar, kota kecil. Untuk sebagian kebiasaan tersebut dikarenakan oleh ketidakmengertian Mahasiswa dengan arti belajar bagi diri sendiri.

Kesembilan, Cita-cita Mahasiswa. Cita-cita merupakan harapan besar bagi Mahasiswa sehingga Mahasiswa selalu termotivasi untuk belajar dengan serius demi menggapai cita-cita tersebut.Dengan mengaitkan pemilikan cita-cita dengan kemampuan berprestasi maka Mahasiswa diharapkan berani bereksplorasi sesuai dengan kemampuannya sendiri. ${ }^{9}$

Adapun Faktor Eksternal, yang berpengaruh pada aktifias belajar. Faktor-faktor eksternal tersebut adalah sebagai berikut:pertama, Dosen Sebagai Pembina Mahasiswa Belajar. Dosen adalah pengajar yang mendidik. Ia tidak hanya mengajar bidang studi yang sesuai dengan keahliannya, tetapi juga menjadi pendidik pemuda generasi bangsanya. Dosen yang mengajar Mahasiswa adalah seorang pribadi yang tumbuh menjadi penyandang profesi bidang studi tertentu. Sebagai seorang pribadi ia juga mengembangkan diri menjadi pribadi utuh. Sebagai seorang diri yang mengembangkan keutuhan pribadi, ia juga menghadapi masalah pengembangan diri, pemenuhan kebutuhan hidup sebagai manusia.

Kedua, Sarana dan prasarana Pembelajaran. Prasarana pembelajaran meliputi sarana olahraga, gedung sekolah ruang belajar, tempat ibadah, ruang kesenian, dan peralatan olahraga. Sarana pembelajaran meliputi buku pelajaran, buku bacaan, alat dan fasilitas laboratorium sekolah dan berbagai media pengajaran yang lain. Lengkapnya sarana dan prasarana pembelajaran merupakan kondisi pembelajaran yang baik. Hal ini tidak berarti bahwa lengkapnya sarana dan prasarana menentukan jaminan melakukan proses pembelajaran yang baik. Justru disinilah muncul bagaimana mengolah sarana dan prasaranapembelajaran sehingga tersenggara proses belajar yang berhasil dengan baik.10

Ketiga, Lingkungan Sosial Mahasiswa. Tiap Mahasiswa dalam lingkungan sosial memiliki kedudukan, peranan dan tanggung jawab sosial tertentu. Dalam kehidupan tersebut terjadi pergaulan seperti hubungan sosial tertentu. Dalam kehidupan tersebut terjadi

\footnotetext{
${ }^{9}$ Wasty Soemanto, Psikologi Pendidikan, (Jakarta: Rineka Cipta, 2010), 130.

10 Slameto, Belajar dan Faktor-Faktor Yang mempengaruhi, (Jakarta: Rineka Cipta, 1991), 75.
} 
hubungan akrab kerjasama, berkompetisi, bersaing, konflik atau perkelahian.

Keempat, Kurikulum yang senantiasa silih berganti. Kurikulum diberlakukan di sekolahadalah kurikulum nasional yang disahkan oleh pemerintah, atau yayasan pendidikan. Kurikulum disusun berdasarkan tuntutan kemajuan masyrakat. Dengan kemajuan dan perkembangan masyrakat timbul tuntutan kebutuhan baru dan akibatnya kurikulum sekolah perlu direkonstruksi. Adanya rekonstruksi itu menimbulkan kurikulum baru. Perubahan kurikulum sekolah menimbulkan masalah seperti tujuan yang akan dicapai mungkin akan berubah, isi pendidikan berubah, kegiatan belajar mengajar berubah serta evaluasi berubah.

\section{Faktor-Faktor Penyebab Terjadinya Kesulitan Belajar.}

Faktor Internal yang mempengaruhi kesulitan belajar antara lain: pertama,Gangguan secara fisik, seperti kurang berfungsinya organ-organ perasaan, alat bicara, gangguan panca indera, cacat tubuh, serta penyakit menahan (alergi, asma, dan sebagainya). Kedua,Ketidakseimbangan mental (adanya gangguan dalam fungsi mental). ketiga,Kelemahan emosional, seperti merasa tidak aman, kurang bisa menyesuaikan diri, tercekam rasa takut, benci, dan antipati serta ketidakmatangan emosi.Keempat,Kelemahan yang disebabkan oleh kebiasaan dan sikap salah. Seperti kurang perhatian dan minat terhadap pelajaran sekolah, malas dalam belajar, dan sering bolos atau tidak mengikuti pelajaran.

Adapun Faktor Eksternal-nya antara lain: pertama,Lingkungan Sekolah, antara lain: Sifat kurikulum yang kurang fleksibel, beban belajar yang terlalu berat bagi murid, Kurangnya alat dan sumber untuk kegiatan belajar dll.Kedua,Lingkungan Keluarga, antara lain :Keluarga tidak utuh atau kurang harmonis, Sikap orang tua yang tidak memperhatikan pendidikan anaknya, Kondisi ekonomi dll.

\section{Problem Waktu Dalam Kegiatan Belajar Mengajar}

Sementara yang menjadi problem dalam waktu dalam kegiatan belajar mengajar, antara lain: pertama, Smoothness, adalah urutan pelajaran yang baik dan mencoba menghindari loncatan-loncatan dari satu topik ke topik yang lain, atau dari pelajaran yang satu ke materi pelajaran yang lain.Kedua, Transition, mengatur dari satu aktivitas ke aktivitas lain, seperti dari mata pelajaran yang satu ke materi pelajaran yang lain, atau dari satu pelajaran ke jam istirahat.Ketiga, Overlapping, kemampuan Dosen 
dalam melakukan interupsi secara diam-diam, tanpa menghentikan pelajaran dan Mahasiswa yang lain tidak paham terhadap apa yang dimaksud Dosen tersebut. ${ }^{11}$

Mengidentifikasi Murid Yang Mengalami Masalah BelajarMurid yang mengalami masalah belajar, dapat diidentifikasi melalui berbagai bentuk, antara lain:pertama,Tes Hasil Belajar.Kedua,Tes Kemampuan Dasar.Ketiga,Skala Sikap dan Kebiasaan Belajar.

\section{Problematika Pembelajaran Statistik Di Perguruan Tinggi Keagamaan Islam (PTKI)}

Matematika/ statistik merupakan salah satu ilmu pendidikan yang utama karena matematika berperan dalam melengkapi ilmu lainnya. Oleh karena itu pendidikan matematika menjadi salah satu pusat perhatian kualitas pendidikan di Indonesia sehingga munculah banyak upaya untuk memperbaiki kualitas pendidikan matematika. Ketika berbicara mengenai pendidikan, maka pembelajaran adalah hal yang paling berkaitan dengan pendidikan. Dalam berlangsungnya proses pembelajaran sering sekali Mahasiswa menemukan objek yang bersifat abstrak terutama dalam pembelajaran matematika dimana keabstrakan objek dari matematika merupakan salah satu karakteristiknya.

Hal ini yang menyebabkan Mahasiswa merasa kesulitan dalam memaknai hal-hal yang abstrak kepada kehidupan nyata dan menyampaikan ide-ide dalam matematika baik secara lisan maupun tulisan. Menurut Jenning dan Dunnemengatakan bahwa, "kebanyakan Mahasiswa mengalami kesulitan dalam mengaplikasikan matematika ke dalam situasi kehidupan riil."

Berdasarkan permasalahan diatas,Dosen dapat memfasilitasi Mahasiswa dengan mengembangkan bahan ajar berpendekatan Realistic Mathematics Education (RME) yaitu dengan mengaitkan masalah matematika dengan lingkungan sehari-hari dan pengalaman nyata yang sering dialami sehingga Mahasiswa diajak berfikir bagaimana menyelesaikan masalah-masalah yang diberikan dengan menggunakan pendekatan yang tidak abstrak lagi.

Menurut Freudenthal, kegiatan RME dalam pembelajarannya di kelas, dimulai dari masalah kontekstual dan memberi kebebasan kepada Mahasiswa untuk dapat mendiskripsikan, menginterpretasikan dan menyelesaikan masalah kontekstual

11 Sri Esti Wuryani Djiwandono, Psikologi Pendidikan,(Jakarta: PT Grasindo, 2008), 294. 
dengan caranya sendiri sesuai dengan pengetahuan awal yang dimiliki. Proses penjelajahan, penginterpretasian, dan penemuan kembali dalam RME menggunakan konsep matematisasi horizontal dan vertikal, yang diinspirasi oleh cara-cara pemecahan informal yang digunakan oleh Mahasiswa.

Matematisasi horizontal, berkaitan dengan pengetahuan yang telah dimiliki Mahasiswa sebelumnya bersama intuisi mereka digunakan sebagai alat untuk menyelesaikan masalah dari dunia nyata. Aktivitas yang dapat digolongkan dalam matematisasi horizontal antara lain: mengidentifikasi masalah, memvisualisasikan masalah dengan cara yang berbeda, mentransformasikan masalah dunia nyata ke masalah matematik, membuat skema,menemukan hubungan-hubungan dan keterkaitan,mengingat aspek-aspek yang serupa dalam masalah yang berbeda, merumuskan masalah nyata dalam bahasa matematika, dan merumuskan masalah nyata dalam model matematika yang telah dikenal.

Sedangkan matematisasi vertical berkaitan dengan proses pengorganisasian kembali pengetahuan yang telah diperoleh dalam simbol-simbol matematika yang lebih abstrak. Aktivitas yang merupakan matematisasi vertikal contohnya: merepresentasikan hubungan-hubungan dalam rumus, menyesuaikan dan menggunakan model matematik yang berbeda, merumuskan model matematik, menghaluskan dan memperbaiki model, memadukan dan mengkombinasikan beberapa model, membuktikan keteraturan, dan merumuskan konsep baru matematika. ${ }^{12}$

Berdasarkan kedua jenis matematisasi ini, dibuatlah pengklasifikasian pendekatan pendidikan matematika. Klasifikasi pendidikan matematika berdasarkan matematisasi horizontal dan vertikal dibagi ke dalam empat tipe:pertama, Mechanistic, atau "pendekatan traditional", yang didasarkan pada "drill-practice" dan pola atau pattern, yang menganggap orang seperti komputer atau suatu mesin (mekanik). Pada pendekatan, baik horizontal dan vertikal mathematization tidak digunakan.

Kedua,Empiristic, dunia adalah realitas, dimana Mahasiswa dihadapkan dengan situasi dimana mereka harus menggunakan aktivitas horizontal mathematization. Treffer mengatakan bahwa pendekatan ini secara umum jarang digunakan dalam pendidikan matematika.

12 Prastiti Tri Dyah, Pengaruh Pendekatan Pembelajaran RME dan Pengetahuan Awal Terhadap Kemampuan Komunikasi dan Pemahaman Matematika Siswa SMP Kelas VII. (Surabaya: Penelitian, 2007), 11. 
Ketiga,Structuralist, atau "Matematika modern", didasarkan pada teori himpunan dan game yang bisa dikategorikan ke horizontal mathematization tetapi di tetapkan dari dunia yang dibuat secara "ad hoc", yang tidak ada kesamaan dengan dunia Mahasiswa.

Keempat, Realistic, yaitu pendekatan yang menggunakan suatu situasi dunia nyata atau suatu konteks sebagai titik tolak dalam belajar matematika. Pada tahap ini Mahasiswa melakukan aktivitas horizontal mathematization. Maksudnya Mahasiswa mengorganisasikan masalah dan mencoba mengidentfikasi aspek matematika yang ada pada masalah tersebut. Kemudian, dengan menggunakan vertical mathematization Mahasiswa tiba pada tahap pembentukan konsep. ${ }^{13}$

Upaya mengembangkan pendekatan dan strategi pembelajaran sudah banyak dilakukan dalam rangka memperbaiki kualitas pendidikan. Dengan modal pengalaman yang dimiliki selama aktif di dunia pendidikan dapat melahirkan inovasi dalam pembelajaran matematika/ statistik, tidak sedikit pula hasil inovasi yang mereka lakukan memberikan hasil yang sangat efektif.

Selain kekuatan dan potensi yang dimiliki, terdapat permasalahan dalam pembelajaran matematika/ statistik. Masalah tersebut antara lain: pertama, Permasalahan yang bersumber dari karakteristik matematika. Keabstrakan matematika, selain menjadikan matematika sebagai ilmu pengetahuan yang dapat memasuki dan berintegrasi dengan ilmu yang lain, maka dalam proses pengajarannya membutuhkan energi yang cukup ekstra untuk dapat menanamkan objek-objek abstrak pada struktur kognitif peserta didik. Sifat hirarki dan sifat yang terstruktur dengan baik dan sitematis adalah bagian yang terpisahkan. Artinya jika Mahasiswa tidak siap dengan pengetahuan prasyarat atau pengetahuan pendahulunya dari materi yang diajarkan, maka Mahasiswa tidak akan menangkap konsep-konsep, prinsip-prinsip, maupun prosedur kajian matematika yang baik. ${ }^{14}$

Dipahami bahwa, MahasiswaPerguruan Tinggi Kegamaan Islam (PTKI) khususnya jurusan Tarbiyah yang kemampuan dasarnya adalah keagamaan, maka ketika menempuh pembelajaran statistik terdapat beberapa kendala terhadap pemahaman isi materi, konsep, struktur kognitif dan metodenya.PTKIseringkali dikesankan sebagai pendidikan yang

13 Ibid.

14 Zaenal Arifin, Membangun Kompetensi Pedagogis Guru Matematika (Landasan Filosofi, Histori, dan Psikologi), (Surabaya: Lentera Cendikia, 2010), 48. 
tradisional dan konservatif, hal ini wajar karena orang memandang bahwa kegiatan pendidikan Islam dihinggapi oleh lemahnya penggunaan metodologis pembelajaran yang cenderung tidak menarik perhatian dan memberdayakan. PTKI terasa kurang concern terhadap persoalan bagaimana mengubah pengetahuan agama yang bersifat kognitif menjadi suatu "makna dan nilai" yang perlu di internalisasikan dalam diri seseorang lewat berbagai cara, media dan forum.

Disamping itu, Metodologi pengajaran di PTKI berjalan secara konvensional-tradisional, yakni menitik beratkan pada aspek korespondensi-tekstual yang lebih menekankan yang sudah ada pada kemampuan anak didik untuk menghafal teks-teks keagamaan daripada isu-isu sosial keagamaan yang dihadapi pada era modern seperti kriminalitas, kesenjangan sosial dan lain lain.Pengajaran di PTKI yang bersandar pada bentuk metodologi yang bersifat statis indoktrinatif-doktriner. ${ }^{15}$

Kedua, Permasalahan yang bersumber dari media. Ketersediaan media dan alat peraga menjadi faktor kendala, apalagi pada konteks pendidikan agama Islam. Karena mayoritas konsennya pada literatur-literatur keagamaan klasik sampai modern.Operational problem (masalah operasional), secara mikro akan berhubungan dengan dengan berbagai komponen di PTKI, misalnya hubungan interaktif lima faktor pendidikan yaitu tujuan pendidikan, pendidik dan tenaga pendidikan, peserta didik dan alat-alat pendidikan (kurikulum, metodologi, manajemen, administrasi, sarana dan prasarana, media pembelajaran, sumber dan evaluasi) dan lingkungan atau konteks pendidikan. Atau bisa bertolak dari hubungan input, proses dan output. Sedangkan secara makro, menyangkut keterkaitan pendidikan Islam dengan sistem sosial, politik, ekonomi, budaya dan agama baik yang bersifat Nasional dan Internasional. ${ }^{16}$

Ketiga, Permasalahan yang bersumber dari bahasa (simbol, huruf dan kata). Dalam matematika khususnya statistik, penggunaan simbol seperti $\Sigma, \geq, \leq, \pi$ dan lainnya akan menjadi kendala tersendiri bagi Mahasiswa untuk memahami lebih detail tentang arti simbol diatas.

Keempat, Permasalahan yang bersumber dari Mahasiswa yang bersangkutan.Tidak semua bisa dipastikan bahwa input Mahasiswadi PTKI tidak memiliki basic dan keahlian dalam

15 Mujtahid, Reformulasi Pendidikan Islam; Meretas Mindset Baru, Meraih Paradigma Unggul. (Malang: UIN-Maliki Press, 2011), 37.

16 Muhaimin, Pemikiran dan Aktualisasi Pengembangan Pendidikan Islam, (Jakarta: Rajawali Pers, 2011), 45. 
matematika, namun pemahaman dan realitas yang terjadi adalah inputnya memiliki kemampuan yang memerlukan pembinaan dan pendidikan yang ekstra di bidang ilmu eksakta.Kebiasaankebiasaan belajar Mahasiswaakan mempengaruhi kemampunanya dalam berlatih dan menguasai materi yang telah disampaikan oleh Dosen. Kebiasaan buruk tersebut dapat berupa belajar pada akhir semester, belajar tidak teratur, menyia-nyiakan kesempatan belajar. ${ }^{17}$

\section{Solusi Alternatif}

Pengelolaan kelas memiliki arti yang luas, sebagaimana Edmund dan Emmer sebagaimana yang dikutip oleh Sri Esti Wuryani, beliau mendefinisikan pengelolaan kelas adalah, tingkah laku Dosen yang dapat menghasilkan prestasi Mahasiswa yang tinggi karena keterlibatan Mahasiswa di kelas, serta tingkah laku Mahasiswa yang tidak banyak mengganggu kegiatan Dosen dan Mahasiswa lain dan dapat menggunakan waktu belajar yang efektif. ${ }^{18}$ Dapat disimpukan bahwa pengelolaan kelas meliputi antara lain:Keterlibatan Mahasiswa di kelas, Sedikit gangguan dan Penggunaan waktu belajar yang efektif.

Pengelolaan kelas dalam perspektif sejarah, cenderung menitik beratkan pada person dan karakter serta sifat yang harus di miliki seorang Dosen/ Dosen sebagai kendali dan nahkoda dalam mengatur serta mendesain kelas. Adapun sifat-sifat yang senantiasa dimiliki seorang Dosen antara lain sebagaiberikut:Sikap tenang, Teguh dan tegas, Rajin,Simpati,Terbuka dan adil,Aturan, sistem dan aturan,Kompeten danKesarjanaan. ${ }^{19}$

Pengelolaan kelas dalam perspektif psikologis, Perkembangan teori-teori tentang pengelolaan kelas berasal dari bagian bidang psikologi.Terdapat dua teori psikologis yang paling umum berhubungan dengan pengaturan kelas berdasarkan teori Skinner dan Roger.Model pengaturan kelas ini dikenal dengan istilah Reinforcement, yang berarti bahwa menggambarkan tingkah laku manusia sebagai hasil dari lingkungan, jika lingkungan dapat dikontrol melalui Reinforcement, maka tingkah laku manusia dapat pula dibentuk dan diubah. Contoh, seorang Dosen yang menanyakan suatu pertanyaan di kelas, ada beberapa Mahasiswa yang mengacungkan tangan mereka, sedangkan Mahasiswa yang

17 Ibid, 52.

${ }^{18}$ Sri Esti Wuryani Djiwandono, Psikologi Pendidikan, 264.

${ }^{19}$ Ibid, 269. 
lain menjawab sambil berteriak. Maka, dengan dengan menggunakan prinsip-prinsip Reinforcement, maka seorang Dosen hanya memberikan kesempatan kepada Mahasiswa yang menjawab dengan mengacungkan tangan terlebih dahulu. ${ }^{20}$

Beberapa pendekatan dalam pengelolaan kelas, Seorang Dosen harus mampu menetapkan pilihan yang tepat dalam melakukan pendekatan untuk mewujudkan pengelolaan kelas yang efektif. Untuk memperjelas masalah pendekatan yang akan dipergunakan itu, di bawah ini akan diketengahkan beberapa alternatif yang dapat dipilih diantaranya: pertama, Pendekatan berdasarkan perubahan tingkah laku Mahasiswa, kedua, Pendekatan berdasarkan suasana emosi Mahasiswa dan hubungan sosial. ${ }^{21}$

Merubah pola pendidikan Islam indoktrinasi menjadi pola partisipatif antara Dosen dan murid. Pola ini memberikan ruang bagi Mahasiswa untuk berpikir kritis, optimis, dinamis, inovatif, memberikan alasan-alasan yang logis, bahkan Mahasiswa dapat pula mengkritisi pendapat Dosen jika terdapat kesalahan. Intinya, pendekatan epistemologi ini menuntut pada Dosen dan Mahasiswa untuk sama-sama aktif dalam proses belajar mengajar. ${ }^{22}$

Ilmu-ilmu yang berbasis pada realitas pengalaman empiris, seperti sosiologi, spikologi, filsafat kritis yang sifatnya membumi perlu dijadikan dasar pembelajaran, sehingga ilmu betul-betul menyentuh persoalan-persoalan dan pengalaman empiris. ${ }^{23}$

Adanya peningkatan profesionalisme tenaga pendidik yang meliputi kompetensi personal, kompetensi pedagogik, kompetensi profesional dan kompetensi sosial. ${ }^{24}$ Sehingga dengan pemenuhan kompetensi inilah, seorang tenaga pendidik mampu menemukan metode yang diharapkan sebaimana harapan dalam kajian epistemologis.

\section{Penutup}

Pengelolaan kelas adalah, tingkah laku Dosen yang dapat menghasilkan prestasi Mahasiswa yang tinggi karena keterlibatan Mahasiswa di kelas, serta tingkah laku Mahasiswa yang tidak

20 Tri Wibowo, Psikologi Pendidikan, (Jakarta: Kencana Prenada Media Group, 2008), 553.

${ }^{21}$ Mulyati, Psikologi belajar, (Yogyakarta: CV Andi Offset, 2005), 50.

22 Sutrisno, Pembaharuan Dan Pengembangan Pendidikan Islam (Yogyakarta: Fadilatama, 2011), 105

${ }^{23}$ Zuhairini, Filsafat Pendidikan Islam, (Jakarta: Bumi Aksara, 1995), 152

${ }^{24}$ Moh. Uzer Usman, Menjadi Guru Profesional, (Bandung: PT Remaja Rosdakarya, 2010), 16. 
banyak mengganggu kegiatan Dosen dan Mahasiswa lain dan dapat menggunakan waktu belajar yang efektif.

Masalah belajar dapat diartikan bahwa suatu kondisi tertentu yang dialami oleh murid dan menghambat kelancaran proses yang dilakukan individu untuk memperoleh suatu perubahan tingkah laku yang baru secara keseluruhan.

Faktor-Faktor Penyebab Terjadinya Kesulitan Dalam Belajar, Faktor Internal yang meliputi: Gangguan secara fisik, Ketidakseimbangan mental (adanya gangguan dalam fungsi mental), Kelemahan emosional, Kelemahan yang disebabkan oleh kebiasaan dan sikap salah. Seperti kurang perhatian dan minat terhadap pelajaran sekolah, malas dalam belajar, dan sering bolos atau tidak mengikuti pelajaran.

Adapun Faktor Eksternal meliputi: Lingkungan Sekolah, antara lain: Sifat kurikulum yang kurang fleksibel, beban belajar yang terlalu berat bagi murid, Kurangnya alat dan sumber untuk kegiatan belajar dll.Lingkungan Keluarga, antara lain : Keluarga tidak utuh atau kurang harmonis, Sikap orang tua yang tidak memperhatikan pendidikan anaknya, Kondisi ekonomi dll.

\section{Daftar Pustaka}

Arifin, Zaenal. Membangun Kompetensi Pedagogis Dosen Matematika (Landasan Filosofi, Histori, dan Psikologi), (Surabaya: Lentera Cendikia, 2010)

Djiwandono, Sri Esti Wuryani. Psikologi Pendidikan, (Jakarta: PT Grasindo, 2008)

Muhaimin, Pemikiran dan Aktualisasi Pengembangan Pendidikan Islam, (Jakarta: Rajawali Pers, 2011)

Mujtahid. Reformulasi Pendidikan Islam; Meretas Mindset Baru, Meraih Paradigma Unggul. (Malang: UIN-Maliki Press, 2011)

Mulyati. Psikologi belajar, (Yogyakarta: CV Andi Offset, 2005)

Nasution, S. Berbagai Pendekatan Dalam Proses Belajar dan Mengajar, (Jakarta: Bumi Aksara, 2000)

Slameto. Belajar dan Faktor-Faktor Yang mempengaruhi, (Jakarta:

Rineka Cipta, 1991)

Sudjana. Metoda Statistika, (Bandung: Tarsito, 2005)

Suherman, Erman, at.al. Strategi Pembelajaran Matematika Kontemporer, (Bandung: UniversitasPendidikan Indonesia, 2003) 
Sutrisno. Pembaharuan Dan Pengembangan Pendidikan Islam (Yogyakarta: Fadilatama, 2011)

Soemanto, Wasty. Psikologi Pendidikan, (Jakarta: Rineka Cipta, 2010)

Syah, Muhibbin. Psikologi Belajar, (Jakarta: PT Grafindo Persada, 2006)

Wibowo, Tri. Psikologi Pendidikan, (Jakarta: Kencana Prenada Media Group, 2008)

Dyah, Prastiti Tri. Pengaruh Pendekatan Pembelajaran RME dan Pengetahuan Awal Terhadap Kemampuan Komunikasi dan Pemahaman Matematika Mahasiswa SMP Kelas VII. (Surabaya: Penelitian, 2007)

Uno, Hamzah B. Perencanaan Pembelajaran, (Jakarta: PT Bumi Aksara, 2011)

Usman,Moh Uzer Menjadi Dosen Profesional, (Bandung: PT Remaja Rosdakarya, 2010)

Zuhairini. Filsafat Pendidikan Islam, (Jakarta: Bumi Aksara, 1995) 